\title{
PELATIHAN PEMBUATAN PAKAN IKAN BAGI PEMUDA DAN PEMBUDIDAYA IKAN PADA MASA PANDEMI COVID-19 DI KABUPATEN ALOR
}

\author{
TRAINING OF FISH FEED MAKING FOR YOUTH AND FISH CULTIVATORS \\ IN THE COVID-19 PANDEMIC TIME IN ALOR DISTRICT \\ ${ }^{1)}$ Fakultas Pertanian dan Perikanan Universitas Tribuana Kalabahi \\ email: yantotell@untribkalabahi.ac.id \\ ${ }^{2)}$ Fakultas Matematika dan Ilmu Pengetahuan Alam Universitas Tribuana Kalabahi \\ email: mautukazakarias@gmail.com \\ ${ }^{3)}$ Dewan Pimpinan Daerah Komite Nasional Pemuda Indonesia Kabupaten Alor \\ email: mandokolimon@gmail.com \\ ${ }^{4)}$ Fakultas Pertanian dan Perikanan Universitas Tribuana Kalabahi \\ email: lande.dina@gmail.com
}

\begin{abstract}
ABSTRAK
Tingginya harga pakan ikan di pasaran mengakibatkan banyak pembudidaya ikan di kabupaten Alor tidak dapat menyediakan pakan ikan secara berkesinambungan. Kebutuhan pakan ikan selama ini hanya mengandalkan pasokan dari luar melalui bantuan Dinas Kelautan dan Perikanan Kabupaten Alor. Ketika terjadi pembatasan akses akibat pandemi Covid-19 di kabupaten Alor, telah mengakibatkan terhentinya rantai pasokan pakan ikan dari luar. Pada sisi lain, para pembudidaya ikan di kabupaten Alor tidak memiliki pemahaman dan keterampilan dalam memproduksi pakan ikan secara mandiri. Dalam kondisi demikian maka kegiatan pengabdian masyarakat perlu dilaksanakan khususnya untuk meningkatkan pemahaman dan keterampilan pembudidaya ikan. Metode yang digunakan dalam kegiatan pengabdian yakni pelatihan formulasi pakan ikan melalui FGD dan praktek pembuatan pakan ikan. Hasil analisis menunjukkan bahwa tingkat pemahaman peserta sebelum mengikuti pelatihan adalah $58,43 \%$ meningkat menjadi $79,76 \%$ setelah mengikuti pelatihan. Berdasarkan hasil analisis maka dapat disimpulkan bahwa perpaduan metode pelatihan dalam bentuk FGD dan praktek kerja memiliki dampak positif dalam peningkatan pemahaman peserta. Secara umum kegiatan pelatihan ini telah meningkatkan pemahaman peserta dengan peningkatan pemahaman sebesar $21,33 \%$.
\end{abstract}

Kata kunci: FGD, Covid-19, Pakan Ikan, Formulasi

\section{ABSTRACT}

The high price of fish feed in the market has resulted in many fish farmers in the Alor district being unable to provide fish feed sustainably. The need for fish feed has so far only relied on supplies from outside through the assistance of the Alor Regency Marine and Fisheries Service. When there was a restriction on access due to the Covid-19 pandemic in the Alor district, it had resulted in the interruption of the supply chain for fish food from outside. On the other hand, fish cultivators in the Alor district do not have the understanding and skills in producing fish feed independently. In such conditions, community service activities need to be carried out in particular to improve the understanding and skills of fish cultivators. The method used in the community service was training in fish feed formulation through FGD and practice of making fish feed. The analysis showed that the participant's level of understanding before attending the training was $58.43 \%$, increasing to $79.76 \%$ after attending the training. Based on the results of the analysis, it can be concluded that the combination of training methods in the form of FGDs and practical work has a positive impact on increasing participant's understanding. In general, this training activity has increased participant's understanding by increasing understanding by $21.33 \%$.

Keywords: FGD, covid-19, Fish Feed, Formulation 


\section{PENDAHULUAN}

Pakan merupakan salah satu komponen utama yang memiliki fungsi penting dalam mendukung keberhasilan usaha budidaya ikan air tawar. Ketersediaan pakan dalam jumlah dan kualitas yang cukup dapat menjamin keberlangsungan siklus budidaya ikan. Pakan menempati posisi tertinggi yakni sekitar 60 - 80\% dari total kebutuhan biaya produksi dalam budidaya ikan secara intensif [1].

Pakan ikan yang dijual di pasaran biasanya memiliki harga yang cukup tinggi. Salah satu faktor penyebabnya adalah beberapa bahan baku pakan ikan seperti tepung ikan, tepung jagung dan tepung kedelai yang masih diimpor dari luar negeri. Padahal bahan baku tersebut masih dapat diperoleh dari lingkungan sekitar pembudidaya ikan.

Berdasarkan data dari Indonesian Feed Mills Association (2015) bahwa kebutuhan impor bahan baku pakan untuk akuakultur Indonesia sejak tahun 2014 - 2019 terus mengalami peningkatan. Pada tahun 2019 tercatat kebutuhan impor bahan baku pakan yakni tepung ikan mencapai 302.000 ton, tepung kedelai mencapai 552.000 ton, dan tepung jagung mencapai 235.000 ton [2].

Tingginya kebutuhan bahan baku impor turut berpengaruh terhadap meningkatnya harga jual pakan ikan. Oleh karena itu para pembudidaya ikan diharapkan dapat memproduksi sendiri pakan ikan dengan memanfaatkan bahan baku lokal yang ada di sekitar mereka untuk menekan biaya produksi.

Bahan baku lokal seperti tepung ikan, tepung jagung dan tepung kedelai sangat mudah diperoleh di wilayah kabupaten Alor. Namun berdasarkan hasil observasi dan wawancara dengan beberapa kelompok pembudidaya ikan diketahui bahwa umumnya pembudidaya ikan air tawar di kabupaten Alor tidak memproduksi sendiri pakan ikan karena keterbatasan pengetahuan dalam formulasi pakan ikan.

Selama ini sebagian besar pembudidaya ikan air tawar di kabupaten Alor hanya mengandalkan pakan ikan yang didatangkan dari luar melalui bantuan Dinas Kelautan dan Perikanan Kabupaten Alor. Namun dengan adanya pembatasan akses akibat pandemi Covid-19, telah mengakibatkan terhentinya rantai pasokan pakan ikan dari luar. Jika kondisi tersebut berlangsung secara terus menerus dalam jangka waktu yang lama maka pembudidaya ikan akan kehabisan stok pakan ikan. Dalam kondisi seperti ini maka proses transfer ilmu pengetahuan tentang formulasi pakan ikan kepada pembudidaya menjadi penting untuk dilakukan.

Pemuda memiliki potensi dan peran penting sebagai agen perubahan. Pemuda identik dengan sosok individu yang energik, berpikir kritis, serta dinamis sehingga memiliki kecenderungan untuk membentuk kelompok atau organisasi tertentu demi mencapai tujuan bersama [3]. Organisasi kepemudaan bisa dibentuk mulai dari daerah 
hingga pada tingkat nasional seperti Karang

Taruna, Organisasi Kemasyarakatan Pemuda (OKP) dan Komite Nasional Pemuda Indonesia (KNPI).

Organisasi kepemudaan memiliki peran strategis dalam pembangunan daerah, termasuk dalam pemberdayaan masyarakat perdesaan. Hal senada terungkap melalui hasil penelitian [4] bahwa pemuda memiliki peran positif secara simultan dan parsial dalam pembangunan masyarakat perdesaan. Lebih lanjut dijelaskan bahwa terdapat hubungan yang erat antara peran pemuda dari aspek ekonomi, pendidikan, dan infrastruktur dalam pembangunan masyarakat perdesaan.

Sejak pandemi Covid-19 melanda hampir seluruh wilayah Indonesia, organisasi pemuda diharapkan dapat menjadi agen pemberdayaan ekonomi masyarakat di wilayahnya masing-masing. Oleh karena itu setiap anggota organisasi pemuda perlu dibekali dengan pengetahuan dan keterampilan yang memadai khususnya dalam bidang pemberdayaan ekonomi masyarakat.

Kegiatan pengabdian yang dilakukan pada masa pandemi Covid-19 saat ini yakni pelatihan pembuatan pakan ikan bagi perwakilan organisasi pemuda dan pembudidaya ikan di wilayah kabupaten Alor. Tujuan pelatihan ini adalah meningkatkan keterampilan pemuda dan pembudidaya ikan agar dapat membuat pakan ikan secara mandiri. Hasil dari kegiatan pelatihan ini diharapkan ada peningkatan pemahaman dan keterampilan pemuda dalam memproduksi pakan ikan sehingga dapat diteruskan kepada pembudidaya ikan di wilayahnya masingmasing.

\section{METODE PELAKSANAAN KEGIATAN}

Metode pengabdian untuk peningkatan kapasitas pemuda dan pembudidaya ikan pada masa pandemi Covid-19 di kabupaten Alor dapat dijelaskan sebagai berikut:

Rancangan Kegiatan. Kegiatan pengabdian dirancang dalam bentuk Focus Group Discussion (FGD) untuk memberikan pemahaman tentang formulasi pakan ikan. Selain itu peningkatan keterampilan juga diberikan melalui pelatihan/praktek pembuatan pakan ikan. Kegiatan FGD dan praktek pembuatan pakan ikan dilaksanakan langsung di lokasi budidaya ikan air tawar milik kelompok pembudidaya ikan air tawar Desa Alim Mebung, Kecamatan Alor Tengah Utara. Kegiatan pengabdian berlangsung pada bulan Oktober 2020 yakni pada masa pandemi Covid-19 sehingga kegiatan dirancang dengan tetap mematuhi protokol kesehatan.

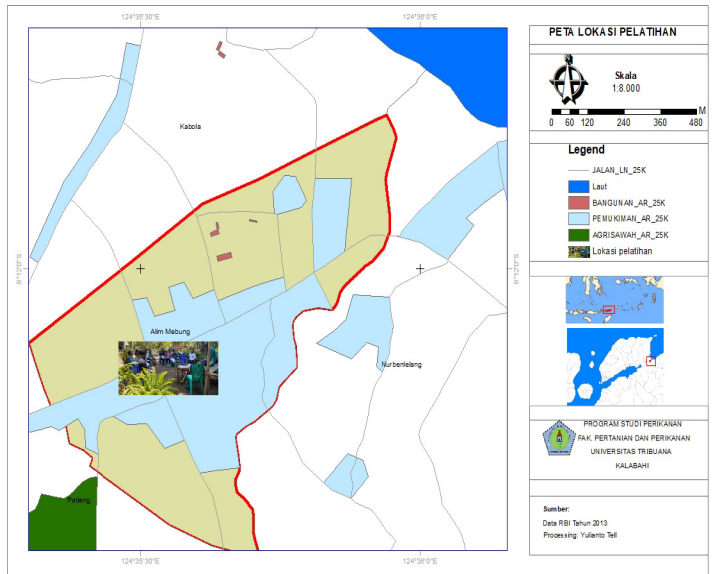

Gambar 1. Peta Lokasi Pelatihan 
Responden/Khalayak Sasaran. Pemilihan responden dilakukan secara purposive dengan pertimbangan adanya Covid-19. Responden yang dipilih mewakili organisasi pemuda yakni pemuda kecamatan Alor Barat Daya (OKP PERMAS ABAD) 1 orang, pemuda kecamatan Alor Tengah Utara dan Lembur (OKP IKMAWEL) 1 orang, pemuda kecamatan Alor Selatan (OKP IMAHLOLONG) 1 orang, pemuda kecamatan Alor Timur Laut (OKP KEMILAU) 1 orang, pemuda kecamatan Pureman dan Alor Timur (OKP SEMATA) 1 orang, DPD KNPI Kabupaten Alor 3 orang, dan perwakilan pembudidaya ikan air tawar 4 orang.

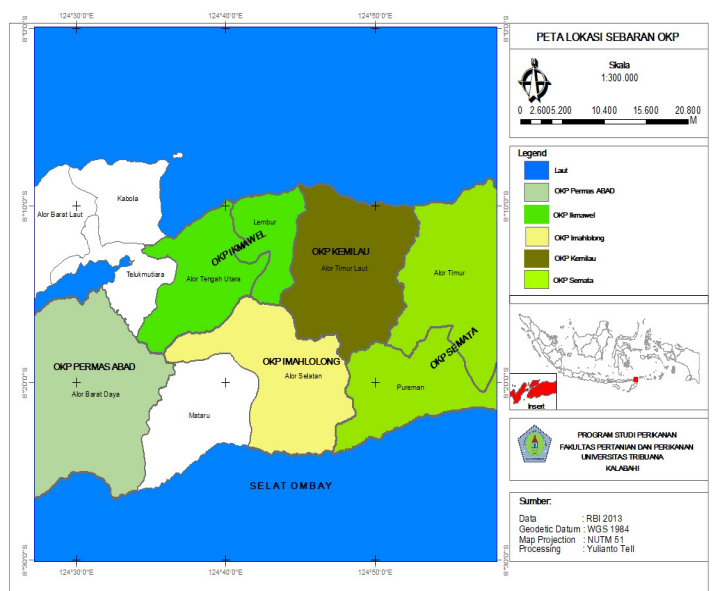

Gambar 2. Peta Lokasi Sebaran OKP

Bahan dan Alat. Bahan dan alat yang digunakan dalam pelatihan ini terdiri atas:

1. Materi pelatihan, meliputi pengetahuan nutrisi pakan (protein, karbohidrat, lemak, vitamin dan mineral), formulasi pakan menggunakan metode Pearsons Square [5] dan prosedur pembuatan pakan ikan mengacu pada SNI 8227:2015 tentang Cara Pembuatan Pakan Ikan yang Baik [6].
2. Bahan-bahan praktek pembuatan pakan ikan meliputi tepung ikan, dedak halus, tepung jagung, tepung tapioka, ampas tahu, probiotik dan air.

3. Peralatan praktek terdiri dari alat penepung manual tipe $500 \mathrm{H}$, alat pencetak pellet manual tipe MKS-PLT 10, timbangan, dulang, sutel, tacu, kompor, dan kaos tangan.

Disain Alat. Peralatan disesuaikan dengan kondisi dan ketersediaan alat serta mempertimbangkan skala produksi pakan yang dihasilkan. Pelatihan yang dilaksanakan saat ini hanya difokuskan pada produksi pakan ikan skala rumah tangga sehingga kinerja peralatan yang digunakan bersifat manual dengan tingkat produktivitas alat sebesar 1 - $10 \mathrm{~kg} /$ produksi.

Teknik Pengumpulan Data. Teknik pengumpulan data dilakukan melalui penyebaran kuesioner awal saat dilakukan FGD, pengamatan secara langsung pada saat praktek pembuatan pakan ikan, serta penyebaran kuesioner akhir setelah selesai pelatihan. Pengumpulan data dilakukan untuk memudahkan dalam analisis tingkat pemahaman peserta FGD terhadap formulasi pakan ikan dan prosedur pembuatan pakan ikan.

Teknik Analisis Data. Data yang diperoleh dianalisis menggunakan analisis deskriptif presentatif [7]. Rumus yang digunakan dalam analisis deskriptif presentatif yaitu:

$$
\%=\frac{n}{N} \times 100 \%
$$

Keterangan:

$\% \quad$ : Deskriptif presentatif 
$\mathrm{n} \quad$ : Nilai yang diperoleh

$\mathrm{N}$ : Jumlah nilai keseluruhan

Selanjutnya hasil analisis data yang diperoleh dipresentasikan berdasarkan kriteria deskriptif presentatif.

Tabel 1. Kriteria Deskriptif Presentatif

\begin{tabular}{cl}
\hline Interval & \multicolumn{1}{c}{ Kriteria } \\
\hline $0 \%<\% \leq 20 \%$ & Sangat rendah \\
$20 \%<\% \leq 40$ & Rendah \\
$40 \%<\% \leq 60$ & Sedang \\
$60 \%<\% \leq 80$ & Tinggi \\
$80 \%<\% \leq 100$ & Sangat tinggi \\
\hline
\end{tabular}

\section{HASIL DAN PEMBAHASAN}

Hasil kegiatan pengabdian masyarakat diuraikan berdasarkan jenis kegiatan yakni kegiatan pelatihan dalam bentuk FGD dan praktek. Kegiatan tersebut diikuti oleh 12 orang peserta yang terdiri dari 5 orang perwakilan OKP, 3 orang perwakilan DPD KNPI Kabupaten Alor dan 4 orang perwakilan kelompok pembudidaya ikan. Persentase jumlah peserta pelatihan dapat dilihat pada Gambar 3.

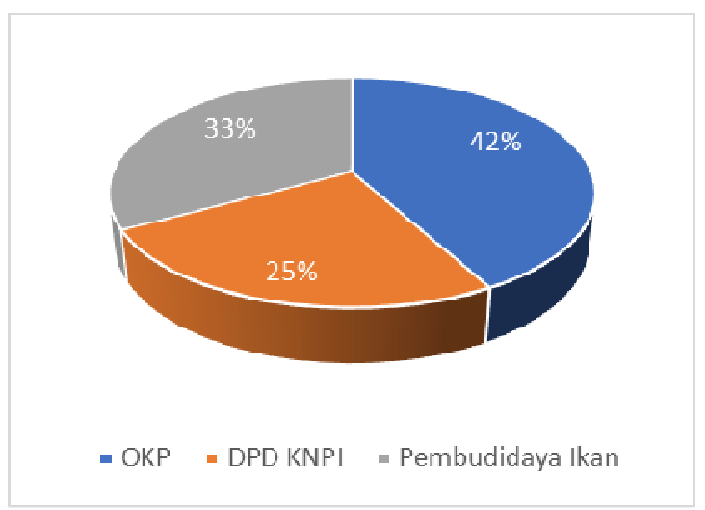

Gambar 3. Persentase Jumlah Peserta

Hasil Pelatihan. Rangkaian kegiatan pelatihan dalam bentuk FGD dan praktek pembuatan pakan ikan dilaksanakan dari awal sampai selesai dengan tingkat partisipasi peserta sebesar $100 \%$. Output yang dihasilkan dalam kegiatan pelatihan ini yakni adanya peningkatan pemahaman serta keterampilan peserta pelatihan dalam pembuatan pakan ikan. Selain itu dihasilkan juga $1 \mathrm{~kg}$ pakan ikan sebagai sampel produk pelatihan untuk uji proksimat sesuai SNI 014087-2006 [8].

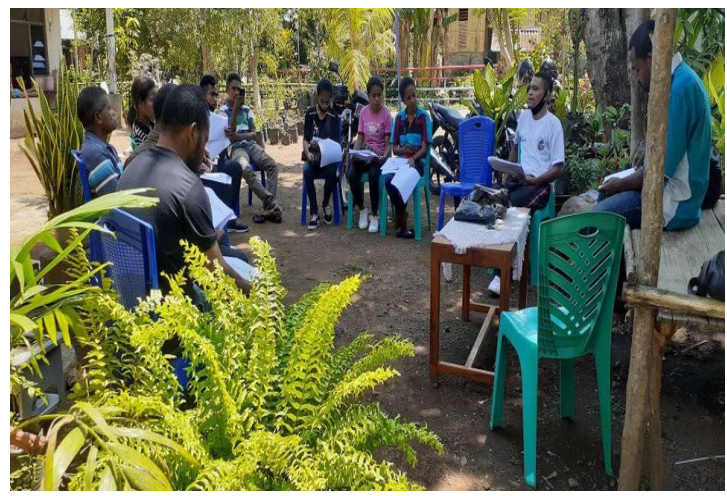

Gambar 4. Kegiatan FGD

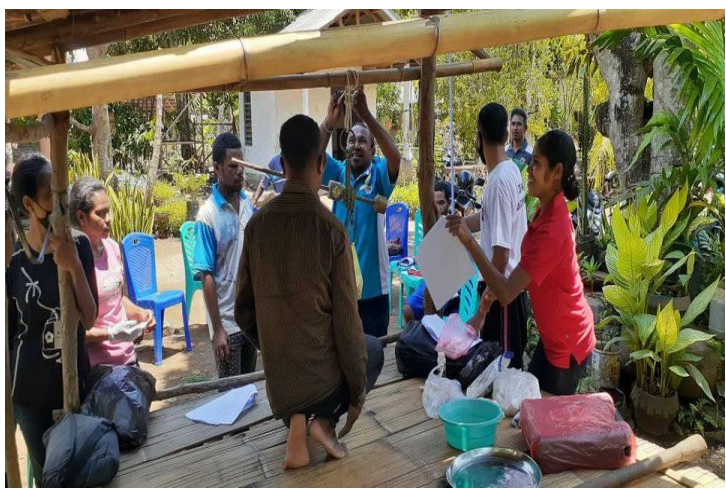

Gambar 5. Kegiatan Praktek

Hasil Analisis Pemahaman Peserta. Analisis tingkat pemahaman peserta pelatihan diawali dengan penyebaran kuesioner. Kuesioner dibagikan kepada peserta dan dilakukan pre test sebelum kegiatan pelatihan berlangsung. Hal ini dimaksudkan untuk mengetahui tingkat pemahaman awal peserta pelatihan. Selanjutnya kuesioner yang sama dibagikan lagi kepada peserta dan dilakukan post test setelah kegiatan FGD dan praktek pembuatan 
pakan ikan selesai dilaksanakan. Hal ini dimaksudkan untuk mengetahui tingkat pemahaman akhir peserta setelah mengikuti serangkaian kegiatan pelatihan.

1. Tingkat pemahaman awal

Analisis tingkat pemahaman peserta dilakukan terhadap beberapa variabel antara lain nutrisi pakan, formulasi pakan, prosedur pembuatan pakan, serta pengenalan bahan baku pakan ikan. Hasil analisis tingkat pemahaman awal peserta pelatihan sebelum pelatihan berlangsung dapat dilihat pada Tabel 2.

Tabel 2. Tingkat Pemahaman Awal

\begin{tabular}{lccc}
\hline \multicolumn{1}{c}{ Variabel } & n & N & \% \\
\hline Nutrisi pakan & 234 & 480 & 48,75 \\
Formulasi Pakan & 45 & 96 & 46,87 \\
Prosedur & 80 & 144 & 55,56 \\
Bahan baku & 230 & 288 & 79,86 \\
\hline
\end{tabular}

Hasil analisis menunjukkan bahwa pemahaman peserta pelatihan terhadap variabel nutrisi pakan ikan sebesar $48,75 \%$ dalam kriteria sedang. Pemahaman formulasi pakan ikan sebesar $46,87 \%$ dalam kriteria sedang. Pemahaman prosedur pembuatan pakan ikan sebesar 55,56\% dalam kriteria sedang. Pemahaman bahan baku pakan ikan sebesar $79,86 \%$ dalam kriteria tinggi.

Rata-rata tingkat pemahaman peserta pelatihan berada pada kriteria sedang kecuali pada item pengenalan bahan baku. Pengenalan bahan baku seperti tepung ikan, dedak halus, tepung jagung, tepung tapioka, dan ampas tahu merupakan bahan-bahan yang mudah diperoleh dan sudah sering digunakan sehingga para peserta memiliki pengetahuan yang baik tentang bahanbahan tersebut.

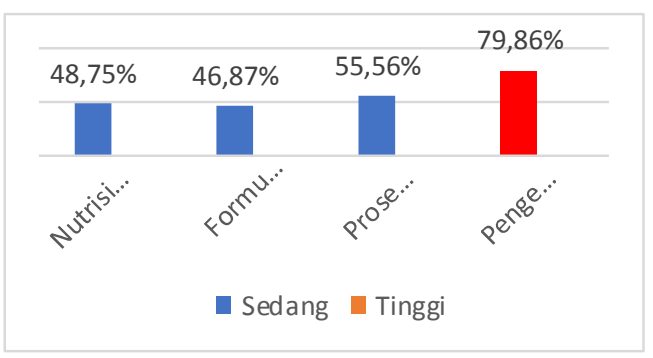

Gambar 6. Tingkat Pemahaman Awal

Secara keseluruhan, hasil analisis menunjukkan bahwa tingkat pemahaman awal peserta sebelum mengikuti pelatihan yakni sebesar 58,43\% dalam kriteria sedang.

Persentase tingkat pemahaman peserta pelatihan sebesar $58,43 \%$ dalam kriteria sedang mengindikasikan bahwa rata-rata peserta pelatihan belum memiliki pemahaman yang baik tentang pakan ikan. Hal ini berarti bahwa para pemuda maupun pembudidaya ikan yang mengikuti pelatihan harus mendapatkan pengetahuan yang baik mengenai formulasi dan cara pembuatan pakan ikan sesuai SNI yang berlaku.

2. Tingkat pemahaman akhir

Hasil analisis tingkat pemahaman peserta pelatihan setelah pelatihan berakhir dapat dilihat pada Tabel 3.

Tabel 3. Tingkat Pemahaman Akhir

\begin{tabular}{lccc}
\hline \multicolumn{1}{c}{ Variabel } & n & N & \% \\
\hline Nutrisi pakan & 342 & 480 & 71,25 \\
Formulasi Pakan & 73 & 96 & 76,04 \\
Prosedur & 115 & 144 & 79,86 \\
Bahan baku & 274 & 288 & 95,14
\end{tabular}


Hasil analisis menunjukkan bahwa pemahaman peserta terhadap variabel nutrisi pakan sebesar $71,25 \%$ dalam kriteria tinggi. Pemahaman formulasi pakan ikan sebesar 76,04\% dalam kriteria tinggi. Pemahaman prosedur pembuatan pakan ikan sebesar 79,86\% dalam kriteria tinggi. Pemahaman bahan baku pakan ikan sebesar 95,14\% dalam kategori sangat tinggi.

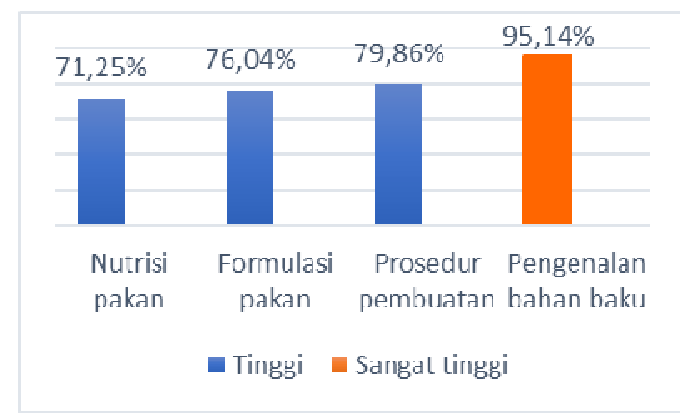

Gambar 7. Tingkat Pemahaman Akhir

Rata-rata tingkat pemahaman peserta setelah mengikuti pelatihan mengalami peningkatan. Secara keseluruhan, hasil analisis menunjukkan bahwa tingkat pemahaman akhir peserta setelah mengikuti pelatihan yakni sebesar 79,76\% dalam kriteria tinggi.

Tingginya tingkat pemahaman peserta setelah mengikuti pelatihan mengindikasikan bahwa rata-rata peserta pelatihan sudah memahami secara baik setiap materi yang diberikan pada saat FGD. Selain itu kegiatan praktek pembuatan pakan ikan secara langsung juga telah memberikan dampak positif bagi peningkatan pemahaman serta keterampilan peserta. Hal ini sesuai dengan pernyataan [9] bahwa kemampuan masyarakat dapat dikembangkan melalui penyuluhan, pengetahuan, dan beberapa bentuk pelatihan keterampilan.

3. Persentase peningkatan pemahaman
Hasil analisis tingkat pemahaman peserta sebelum dan sesudah pelatihan, diketahui bahwa telah terjadi peningkatan pemahaman peserta pelatihan. Hasil analisis tingkat pemahaman peserta sebelum pelatihan yakni sebesar $58,43 \%$ meningkat menjadi $79,76 \%$ setelah mengikuti pelatihan.

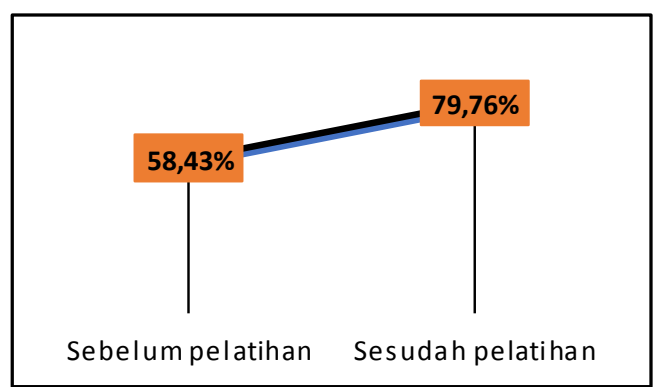

Gambar 8. Persentase Peningkatan

Pemahaman Peserta Pelatihan

Berdasarkan grafik tersebut di atas dapat dijelaskan bahwa telah terjadi peningkatan pemahaman peserta pelatihan sebesar 21,33\%. Dengan demikian hasil pengabdian ini dapat merekomendasikan para peserta untuk menjadi agen pemberdayaan masyarakat dalam pembuatan pakan ikan di wilayahnya masing-masing.

\section{KESIMPULAN}

Berdasarkan hasil pelatihan dan analisis data maka disimpulkan bahwa perpaduan metode pelatihan dalam bentuk FGD dan praktek kerja memiliki dampak positif dalam peningkatan pemahaman peserta. Secara umum kegiatan pelatihan ini telah meningkatkan pemahaman peserta dengan peningkatan pemahaman sebesar 21,33\%. 


\section{SARAN}

Beberapa saran yang disampaikan sebagai rekomendasi dari hasil pelatihan adalah sebagai berikut:

1. Perpaduan antara metode pelatihan FGD dan praktek kerja dapat direkomendasikan untuk digunakan dalam pelatihan peningkatan kapasitas masyarakat;

2. Setiap pemilihan bahan baku dan proses pembuatan pakan ikan harus memperhatikan kandungan nutrisi serta mengacu pada SNI yang berlaku;

3. Setiap produk yang dihasilkan dari kegiatan pembuatan pakan ikan secara mandiri harus dilakukan uji proksimat terlebih dahulu sebelum diaplikasikan pada ikan-ikan budidaya.

\section{UCAPAN TERIMAKASIH}

Ucapan terima kasih patut disampaikan kepada Universitas Tribuana Kalabahi dan Yayasan Tribuana Alor yang telah mendukung kegiatan pelatihan masyarakat melalui dana pengabdian internal Perguruan Tinggi. Ucapan terima kasih juga patut disampaikan kepada Dewan Pimpinan Daerah (DPD) Komite Nasional Pemuda Indonesia (KNPI) Kabupaten Alor selaku mitra yang telah menginisiasi kegiatan sekolah lapang bagi masyarakat Kabupaten Alor.

\section{REFERENSI}

[1] Mulia, D. S. et al. 2015. 'Peningkatan Kualitas Ampas Tahu sebagai Bahan Baku Pakan Ikan dengan Fermentasi Rhizopus oligosporus', Sainteks, 12(1), pp. 10-20.

[2] Usman. 2017. 'Pembuatan pakan ikan berbahan baku lokal': Maros: Balai Penelitian dan Pengembangan Budidaya Air Payau, pp. 1-39.

[3] Sarifudin et al. 2019. 'EDPERDAY (Edukasi Pertanian Swadaya): Upaya Pemberdayaan Pemuda Pertanian dalam Lahan Edukasi Sayur Organik', Jurnal Pengabdian kepada Masyarakat (Indonesian Journal of Community Engagement), 5(2), pp. 304-317.

[4] Harahap, S. R. Y. 2017. 'Peran Pemuda dalam Pembangunan Masayarakat Perdesaan ( Studi Kasus : di Kecamatan Torgamba Kabupaten Labuhanbatu Selatan )', Tesis. Medan: Universitas Sumatera Utara, p. 97 halaman.

[5] Gusrina 2008. Budidaya Ikan Jilid 2. 2nd edn. Edited by TIM. Jakarta: Direktorat Pembinaan Sekolah Menengah Kejuruan.

[6] Standar Nasional Indonesia. 2015. Cara Pembuatan Pakan Ikan yang Baik. Jakarta: Badan Standardisasi nasional.

[7] Anto, Z. 2011. 'Pemahaman Masyarakat di Kecamatan Gunungpati Kota Semarang Terhadap Keamanan Jaringan dan Instalasi Listrik Rumah Tangga'. Semarang: Fakultas Teknik Universitas Negeri Semarang, p. 103.

[8] Standar Nasional Indonesia. 2006. Pakan Ikan Lele. Jakarta: Badan Standardisasi Nasional.

[9] Holinesti, R. et al. 2020. 'Pelatihan Pengolahan Ikan Air Tawar Sebagai Potensi Lokal untuk Peningkatan Ekonomi Keluarga di Nagari Alahan Panjang Kecamatan Lembah Gumanti Kabupaten Solok', Logista-Jurnal Pengabdian kepada Masyarakat 4(2), pp. 32-40. 